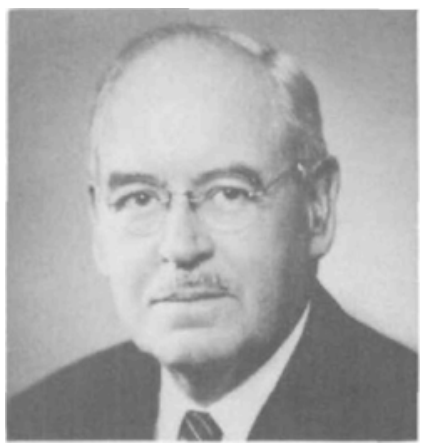

\title{
History of Canadian Anaesthesia
}

\section{Dr. C.H. Robson $(1884-1969)$}

Before World War I only three anaesthetists in Toronto were engaged in the full-time practice of anaesthesia. One of them was Dr. C.H. Robson, who worked at The Hospital for Sick Children and is considered to have been the first full-time paediatric anaesthetist in Canada.

Charles Harold (Robby) Robson was born in New Westminster, British Columbia, on July 18, 1884. After attending neighbouring schools, he obtained the B.Pharm. in 1904, the M.A. in 1908 (from Columbian College) and the M.D. , C.M. in 1913 (from McGill). He intemed at the Montreal General Hospital and then trained in anaesthesia at the Royal Victoria Hospital in Montreal. Early in the Great War he went overseas to France with No. 1 Canadian General Hospital, but in 1916 he was ordered to Ramsgate, England, as Senior Consultant in Anaesthesia to the Canadian Army, to found a school to train Army anaesthetists. It was here that Dr. Robson became noted for his technique of digital tracheal intubation.

Dr. Robson returned to Canada in 1919, and joined the staff of The Hospital for Sick Children as Chief Anaesthetist. He remained there for the rest of his professional career, but he also practised at the Christie Street DVA Hospital, Davisville Military Hospital and, from 1925, Toronto Hospital for Tuberculosis, Weston.

Between the two world wars medical and anaesthetic practice differed profoundly from today. Remuneration was limited, and Dr. Robson had difficulty in making a living, despite being the sole full-time anaesthetist at The Hospital for Sick Children and on staff at three other hospitals. Few could afford to pay any fee, and any referring doctor could administer general anaesthesia to his own private, fee-paying patients. Only in 1950 was the administration of anaesthesia restricted to members of the Department of Anaesthesia at The Hospital for Sick Children.

In this period most anaesthetics at The Hospital for Sick Children consisted of open-drop ethyl chloride and ether with air or added oxygen. Anaesthesia for "T's and A's" constituted about one-third of all anaesthetics, ether being given by open drop followed by insufflation with air from a Junkers bottle. In a few other cases a mixture of nitrous oxide and oxygen or ethylene and oxygen was delivered from a variety of ancient anaesthesia machines, including a McKesson, a Heidbrink and even a Clover inhaler. Although tracheal intubation was performed only rarely, Dr. Robson maintained his ability to intubate small children manually using firm red rubber tubes.

In these times academic pursuits were necessarily limited, money for research being almost nonexistent. Dr. Robson was appointed Clinical Demonstrator in 1935. His only known paper ("Anaesthesia in Children"), was published in 1936 in the American Journal of Surgery. He was renowned for another paper, never published, that decried the use of any premedication (including atropine) in children. He was a frequent speaker on many topics related to paediatric anaesthesia, and he made a movie on the hazards of the immediate postoperative period. Throughout his tenure, he trained a generation of anaesthetists, at least four of whom became chairmen of teaching departments.

Following World War II numerous anaesthetists from the armed forces and the universities became available, and anaesthesia became increasingly complex. Dr. Robson continued as Chief of Anaesthesia but retired from this position in 1951 .

Robby married Flora Dalgleish, a Nursing Sister of No. 1 Canadian General Hospital, in 1916. Two of their sons became doctors and the third became an engineer.

After a lifetime of service, Dr. Charles Harold Robson died at Sunnybrook Hospital, Toronto, on January 2, 1969 , aged 84.

A.W. Conn MD FRCPSC, Toronto 